\title{
The petrological characteristics and significance of organic-rich shale in the Chang 7 member of the Yanchang Formation, south margin of the Ordos basin, central China
}

\author{
Sen $\mathrm{Li}^{1} \cdot$ Ru-Kai Zhu ${ }^{1,2,3} \cdot$ Jing-Wei Cui ${ }^{1,2,3} \cdot$ Zhong Luo ${ }^{1,2,3} \cdot$ Jing-Gang Cui ${ }^{1,2,3} \cdot$ Han Liu' ${ }^{1} \cdot$ Wei-Qiang Li ${ }^{1}$
}

Received: 19 September 2018 / Published online: 13 November 2019

(c) The Author(s) 2019

\begin{abstract}
The organic-rich shale of the Chang 7 member is the most important source rock in the Ordos basin. The sedimentary environment and the controlling factors of organic matter enrichment, however, are still in contention. In this investigation, the Yishicun outcrop, located on the south margin of the Ordos basin, has been considered for the study. X-ray diffraction, polarizing microscopy, field emission scanning electron microscopy and cathodoluminescence (CL) were used to investigate the petrological features of the organic-rich shale. The content of volcanic ash and the diameter of pyrite framboid pseudocrystals were measured to illustrate the relationship between oxygen level, ash content and the enrichment of organic matter. It has been found that the diameter of pyrite framboid pseudocrystals has a strong correlation with the total organic carbon, demonstrating that the redox status degree of the water column has a positive impact on the enrichment of organic matter. Additionally, with an increase in the ash content, the content of organic matter increased at first and then decreased, and reached a maximum when the ash content was about $6 \%$, illustrating that the ash input has a double effect on the enrichment of organic matter.
\end{abstract}

Keywords Organic-rich shale $\cdot$ Volcanic ash $\cdot$ Framboidal pyrite pseudocrystal $\cdot$ Chang 7 member $\cdot$ Ordos basin

\section{Introduction}

The controlling factors of the accumulation of organic matter include primary productivity, preservation of organic matter and the rate of sedimentation (Katz 2005). Considering different factors, many studies proposed multiple approaches for the accumulation of organic matter, for example, the high primary productivity mode and the preservation mode.

The former refers to the productivity in the lacustrine or ocean environment as the critically necessary controlling factor for the accumulation of organic matter. When

Edited by Jie Hao

Sen $\mathrm{Li}$

geolisen@foxmail.com

1 Research Institute of Petroleum Exploration and Development, Beijing 100083, China

2 Tight Oil and Gas Research Center of National Energy, Beijing 100083, China

3 Key Lab of Oil and Gas Reservoir of PetroChina, Beijing 100083, China there is a large input of nutrient content into the basin, algal blooms induce the accumulation of organic matter in the sedimentary rock (Lei et al. 2010; Meng et al. 2012). The methods that are useful in evaluating the primary productivity include trace element indexes and stable carbon isotope measurements. Elements such as $\mathrm{Ba}, \mathrm{P}, \mathrm{Cu}, \mathrm{Ni}$ and $\mathrm{Zn}$ are effective tools to represent the level of primary productivity (Li et al. 2015; Zhang et al. 2017b), and studies have proposed that the presence of an excess amount of Ba can assess the productivity more precisely by eliminating the impact of terrestrial input ( $\mathrm{Li}$ et al. 2015). Utilizing stable carbon isotope measurements is another approach to check the level of productivity in the lacustrine environment. In surface water, ${ }^{12} \mathrm{C}$ is more easily absorbed by algae and other planktons, which make the carbon isotope ratio in the water column become heavier (enriched in ${ }^{13} \mathrm{C}$ ). Therefore, the heavier the carbon isotope ratio in the carbonate, the more likely a high level of paleo-productivity would have been (Zhang et al. 2017a).

The latter refers to a low oxygen content in the water column as the main controlling factor. Before being buried by the sediment, the organic matter is exposed to the 
bottom water. If this is anoxic or euxinic, the organic matter can be preserved well at the sediment-water interface (Betts and Holland 1991; Demaison and Moore 1980). Multiple inorganic and organic geochemical methods can be used to evaluate the oxygen content of water body, such as U/Th, V/ $\mathrm{Cr}, \mathrm{V} / \mathrm{Sc}, \mathrm{V} / \mathrm{V}+\mathrm{Ni}, \mathrm{Ni} / \mathrm{Co}, \mathrm{C} / \mathrm{S}, \mathrm{S}$ isotope (Yang et al. 2010; Zhang et al. 2017b; Li et al. 2017), $\beta$-carotene, pristane/ phytane and diahopane/hopanoid (Zhang et al. 2017b; Li et al. 2017; Wang et al. 2017).

The organic-rich shale in the Chang 7 member is the most important source rock in the Mesozoic in the Ordos basin (Yang and Zhang 2005). In order to explore the controlling factors of high-quality source rock, countless studies have already been reported (Zhang et al. 2008; Yang et al. 2010; Er et al. 2015; Sun et al. 2015; Ma et al. 2016; Li et al. 2017; Wang et al. 2017; Zhang et al. 2017b; He et al. 2019).

The sedimentary environment of the Chang 7 member, however, is still in dispute. Earlier studies showed a low level oxygen content based on inorganic geochemistry (Yang et al. 2010; Sun et al. 2015; Ma et al. 2016; Li et al. 2017). At the same time, biomarkers indicated that the water body was oxic (Yang et al. 2010). The biomarkers, however, also indicated that the water column was reducing based on shale samples collected from the city of Tongchuan, on the south margin of the Ordos basin ( $\mathrm{Li}$ et al. 2017). This paradox caused by geochemistry could be due to the trace elements, the contents of which are under different influences such as terrestrial input, type of organic matter or early diagenesis (Tribovillard et al. 2006). In the Chang 7 period, there were strong tectonic movements due to the Qinling Mountain subduction, making Chang 7 be accompanied by hydrothermal activity (He et al. 2016) and volcanic eruptions (Qiu et al. 2009). Consequently, the geochemical indicators are not technically reliable to identify the sedimentary environment of the Chang 7 period, and thus the issue needs further discussion.

The diameter distribution of framboidal pyrite has been considered to be an effective tool to understand the sedimentary environment (Wilkin et al. 1996; Wilkin and Barnes 1997; Wignall and Newton 1998). According to the previous study (Wilkin and Barnes 1997), it is known that the formation of framboidal pyrite has several steps, which include the formation of iron monosulfide microcrystals, transformation from monosulfide to greigite, aggregation of ferromagnetic greigite microcrystals and the conversion of greigite framboids to pyrite. Greigite is a key material in the growth process of framboidal pyrite (Wignall and Newton 1998). The magnetism of greigite is one of the driving factors causing iron sulfide microcrystals to assemble while the formation of greigite occurs at the redox boundary. Consequently, the formation location of framboidal pyrite is at the same place as the greigite and ceases to grow away from the boundary. Therefore, under euxinic conditions where the redox boundary is in the water column and growing time is limited, smaller framboidal pyrite in a narrow size range is formed. On the other hand, under oxic conditions, the boundary is at or below the sediment-water interface. The size of framboids formed in the sediments is governed by the availability of reactants locally, and the size in general is larger and varying. The framboidal pyrite, therefore, can record a range of redox conditions persistently from euxinic, anoxic, dysoxic to oxic (Wilkin et al. 1996). There are abundant pyrites in the organic-rich shale of the Chang 7 member. A few studies have documented the diameter distribution of framboidal pyrite (Wang et al. 2017; Zhang et al. 2017b), but not systematically.

As for the primary productivity during the Chang 7 period, some researchers have argued that the primary productivity was high (Sun et al. 2015; Zhang et al. 2017b). The same conclusion was suggested by the carbon isotope fluctuations (Wang 2015). Xiong et al. (2015) demonstrated that the strong tectonic activities during the Chang 7 period played an important role in the productivity. Hydrothermal activity, especially the volcanic ash input, brought major nutrients such as $\mathrm{Fe}, \mathrm{P}$ and $\mathrm{Cu}$ to the lake (Zhang et al. 2009), which created the algal blooms. Li $(2007,2009)$ suggested that the organic-rich shale has a similar spatial distribution compared to the volcanic ash, and the ash was mostly developed during the Chang 7 period, indicating that the ash had a positive impact on organic matter accumulation in the source rock. Meanwhile, based on laboratory experiments (Duggen et al. 2007; Langmann et al. 2010; Lin et al. 2011), it is considered that the effect of volcanic ash on algal growth was much more complicated. Accordingly, the action of volcanic ash on the enrichment of organic matter in the Chang 7 period is not clear and thus worth investigating.

On this context, a Chang 7 outcrop, which is adjacent to the city of Tongchuan, located on the south margin of the Ordos basin, was considered for the study. The petrological characteristics of the organic-rich shale have been described in detail, on the basis of which the content of volcanic ash and the size of pyrite framboid pseudocrystals in the shale have been measured to evaluate the influence of ash and the redox status in the water column.

\section{Geological setting}

The Ordos basin is a superimposed basin located at the center of China (Fig. 1a, c), and its area is about $37 \times 10^{4} \mathrm{~km}^{2}$. In the Paleozoic, it was a cratonic basin where marine and transitional sediment deposited, and it became a continental lacustrine basin in the Mesozoic. Based on the tectonic features of the basin, it was subdivided into six tectonic sub-units, which include the Weibei uplift, Yishai slope, Tianhuan depression, Yimeng uplift, West thrust belt 


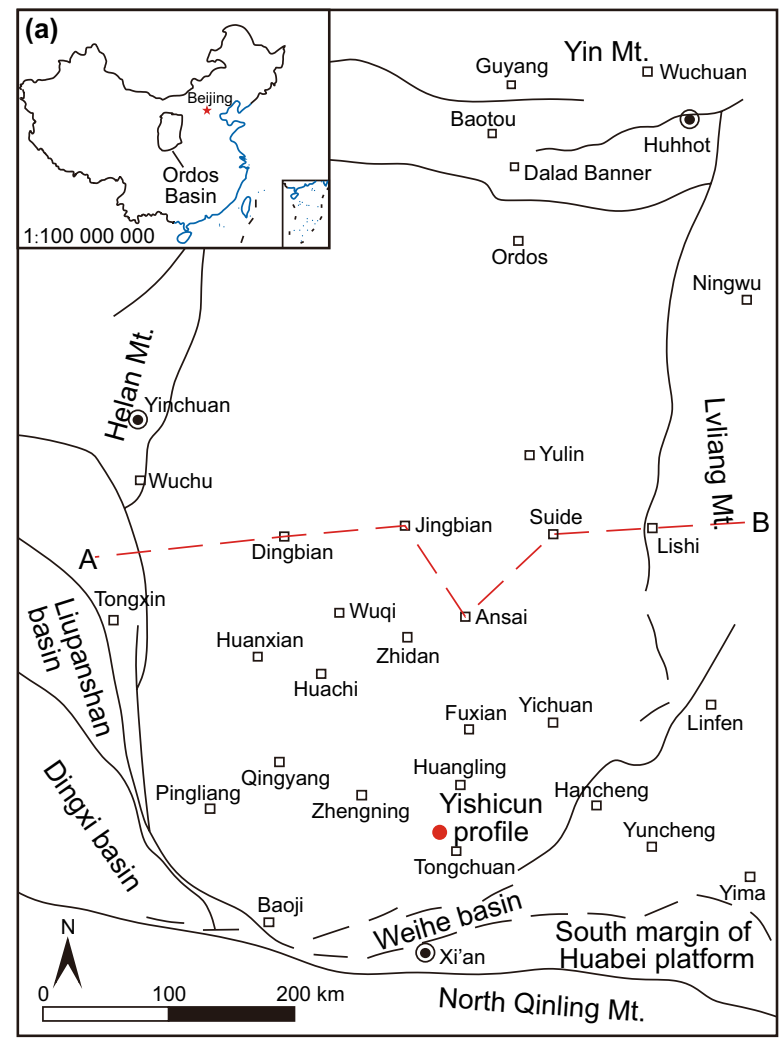

\begin{tabular}{|c|c|c|c|c|c|}
\hline (b) Age & Formation & Member & Lithology & Thickness & $\begin{array}{l}\text { Sedimentary } \\
\text { Facies }\end{array}$ \\
\hline \multirow{9}{*}{ Triassic } & \multirow{9}{*}{ Yanchang } & Chang 1 & 1 & $100-240$ & $\begin{array}{c}\text { Fluvial-lacustrine } \\
\text {-swamp }\end{array}$ \\
\hline & & Chang 2 & $\begin{array}{l:c} & \cdots \\
-1 & \cdots \\
\end{array}$ & $120-160$ & \multirow{4}{*}{ Fluvial-lacustrine } \\
\hline & & Chang 3 & $1 \cdots$ & $120-135$ & \\
\hline & & Chang $4+5$ & $-1 \quad \ldots$ & $90-100$ & \\
\hline & & Chang 6 & 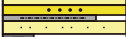 & $80-110$ & \\
\hline & & Chang 7 & $\begin{array}{llll}-1 & & \\
- & \ldots\end{array}$ & $85-110$ & Deep lake \\
\hline & & Chang 8 & 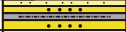 & $60-90$ & \multirow{2}{*}{ Lacustrine } \\
\hline & & Chang 9 & 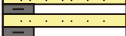 & $90-120$ & \\
\hline & & Chang 10 & \begin{tabular}{|c|}
$\because \because \because$ \\
$\because \because \because$ \\
$\because \because \because$ \\
$\because \because$ \\
\end{tabular} & $200-320$ & Fluvial \\
\hline \begin{tabular}{|l|}
- \\
$\cdots$
\end{tabular} & \multirow{2}{*}{\multicolumn{2}{|c|}{$\begin{array}{l}\text { Mudstone } \\
\text { Fine grained sandstone } \\
\text { Mid-fine grained } \\
\text { sandstone }\end{array}$}} & \multicolumn{2}{|c|}{ 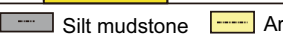 } & \multirow{2}{*}{$\begin{array}{l}\text { Argillaceous siltstone } \\
\text { Coal } \\
\text { stone }\end{array}$} \\
\hline \begin{tabular}{|l|l}
$\cdots$ \\
s
\end{tabular} & & & Coarse gra & ed sandstor & \\
\hline
\end{tabular}

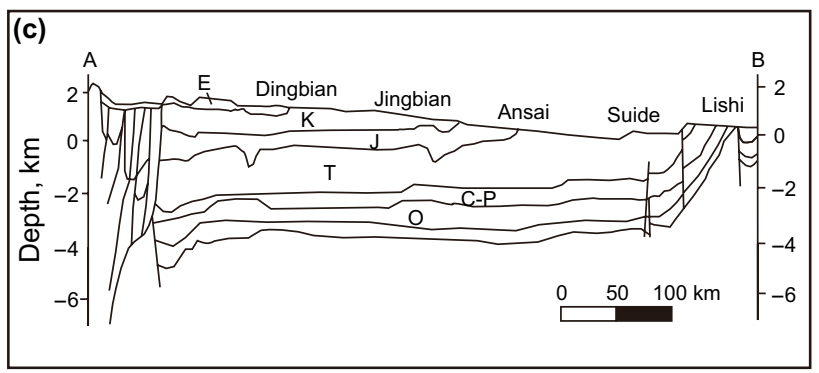

Fig. 1 Geological background of Yanchang Formation and Ordos basin Modified from Cui et al. (2019)

and the Shanxi Folded zone. In the Triassic, the Yanchang Formation recorded the entire lacustrine evolution process (Fig. 1b). The sediments of the Chang 10 and Chang 9 members recorded the initial stage of the basin subsidence, the maximum flooding surface occurred in the Chang 7 period, and the lake became small and disappeared in the late Triassic. The sedimentary facies of the lower part were fluvial and deltaic, those of the middle part were lacustrine, and those of the upper part were fluvial. In the Chang 7 period, the water became deeper because of the thrust napping effect of the North Qinling Mountain (Fu et al. 2013), and a widely distributed organic-rich shale with kerogen types I and II developed in the basin, and it also became the most important source rock in the Mesozoic petroleum system. The Yishicun outcrop situated at the north of the city of Tongchuan is on the south margin of the Ordos basin. The Chang 7 member is nearly horizontal and is mainly composed of organic-rich shale and ash intervals.

\section{Experimental conditions and methods}

The compositions of whole rock and clay minerals of shale were analyzed by a TTR X-ray diffractometer (Rigaku Corporation, Japan). The XRD was carried out according to the industry standard, SY/T 5163-2010. The whole rock mineral analysis was carried out on a 200 -mesh powder sample, and the mass percentage of each mineral was calculated by using the analysis software with reference to the $\mathrm{K}$ value of international standard sample. The XRD analysis of the composition of clay minerals has several steps. The first step is to extract the clay minerals in suspension. The second step is to make the directional tablet which was dried naturally at room temperature. The third step is to saturate the tablet in ethylene glycol at $60{ }^{\circ} \mathrm{C}$ for $8 \mathrm{~h}$, and the fourth step is to heat the tablet at $550{ }^{\circ} \mathrm{C}$ for $2.5 \mathrm{~h}$. The TOC value of organic-rich shale was measured by a LECO CS-230 carbon sulfur analyzer, and the test conditions refer to the national standard, GB/T 19145-2003.

To observe thin section, a BX15 polarizing microscope (OLYMPUS) was used, and a field emission scanning electron microscope (FESEM) (Quanta 450F) equipped with an energy-dispersive spectrometer (EDS) (5030) was used to observe the samples in detail. To avoid the effects of charging, an auto-carbon coater (K950X, EMITECH) was used to coat carbon on the thin section which was fixed on the sample holder using a conductive adhesive. In CL experiments, a polarizing microscope (LEICA DM 4500P, LEICA) was combined with CL (CL8200 MK5-1, Cambridge Image Technology Ltd. (CITL)), the working 
Table 1 Descriptive statistics of framboid size distribution

\begin{tabular}{|c|c|c|c|c|c|c|c|c|}
\hline Sample & TOC, wt $\%$ & $\mathrm{MaxD}, \mu \mathrm{m}$ & $\operatorname{MinD}, \mu \mathrm{m}$ & $\mathrm{AD}, \mu \mathrm{m}$ & S.D., $\mu \mathrm{m}$ & $N$ & View & $\begin{array}{l}\text { Abundance } \\
\text { (N/view) }\end{array}$ \\
\hline YSC-51-82 & 30.7 & 11.7 & 2.1 & 6.5 & 1.45 & 1238 & 83 & 14.9 \\
\hline YSC-51-31 & 24.8 & 15.3 & 3.3 & 6.4 & 1.5 & 865 & 88 & 9.83 \\
\hline YSC-51-44 & 21.3 & 12.0 & 2.3 & 6.2 & 1.4 & 509 & 62 & 8.2 \\
\hline YSC-51-123 & 18.8 & 12.1 & 2.6 & 6.3 & 1.4 & 544 & 77 & 7 \\
\hline YSC-51-42 & 18.1 & 17.1 & 2.0 & 6.3 & 1.58 & 974 & 121 & 8.0 \\
\hline YSC-29A-64 & 15.4 & 19.7 & 2.9 & 6.5 & 2.26 & 443 & 80 & 5.3 \\
\hline YSC-51-10 & 14.7 & 25.2 & 2.8 & 6.2 & 2.04 & 846 & 93 & 9.1 \\
\hline YSC-18-14 & 10.5 & 25.1 & 4.7 & 10.8 & 3.3 & 183 & 87 & 2.1 \\
\hline YSC-38-22 & 8.72 & 25.3 & 3.2 & 9.4 & 3.8 & 125 & 36 & 3.5 \\
\hline YSC-18-3 & 7.65 & 23.6 & 5.0 & 11.4 & 3.5 & 402 & 105 & 3.8 \\
\hline YSC-42-10 & 3.21 & 24.7 & 5.4 & 11.9 & 3.7 & 204 & 59 & 3.4 \\
\hline
\end{tabular}

MaxD maximum diameter, MinD minimum diameter, $A D$ average diameter, S.D. standard deviation, $N$ number of FPPs

voltage and the beam current of which were $15 \mathrm{kV}$ and $320 \mu \mathrm{A}$, respectively.

The pyrite size was measured using a carbon-coated thin section and was viewed in backscattered mode at $1600 \times$ magnification in the FESEM to determine the morphology and size distribution. At least 100 framboids were measured from each sample using AxioVision software (Table 1).

The estimation of volcanic ash content was divided into three steps. In the first step, the images of organic shale with different TOCs were taken using a polarized microscope under both plane polarized light and reflected light. In the second step, identification of ash in each image and its area was accomplished using AxioVision software, and also the proportion of ash in the image was calculated which is similar to estimating the plane porosity. In the last step, the average ash content of each sample was calculated and a cross-plot between ash content and TOC was made. All the above-mentioned experiments were accomplished in the Central Laboratory of Geological Sciences at the Research Institute of Petroleum Exploration and Development.

\section{Results}

\subsection{Petrological characteristics of organic-rich shale}

Based on the XRD results, the main minerals in the shale were found to be quartz, clay, jarosite and feldspar. The content of quartz varied between $24.3 \%$ and $69 \%$ with an average of $25.6 \%$. The content of feldspar was relatively low. The average content of plagioclase and orthoclase was 3\% and $7 \%$, respectively, and the content of jarosite was from $3.6 \%$ to $20.1 \%$ (Table 2). The TOC of organic-rich shale was between $1.4 \%$ and $30.7 \%$.

\subsubsection{Felsic minerals}

Under the polarizing microscope, the interlayers of quartz stripes with clay minerals (Fig. 2a, b, j) could be noted and the boundary of each grain cannot be observed clearly, where some of them are elongated like a band (Fig. 2c). Under CL observation, the stripe-shaped quartz is brown, whereas feldspar is bright blue with random distribution (Fig. 2d, e, f). Based on FESEM work, it could be observed that the stripe-like quartz is composed of a number of quartz particles with mosaic edges (Fig. 2j, k).

\subsubsection{Jarosite}

Jarosite is a typical weathering product in the outcrop. Its general chemical formula is $\mathrm{AB}_{3}\left(\mathrm{XO}_{4}\right)_{2}(\mathrm{OH})_{6}$, where $\mathrm{A}$ is always $\mathrm{K}^{+}, \mathrm{Na}^{+}$or other positive ion, $\mathrm{Fe}^{3+}$ usually represents the position of $\mathrm{B}$, and $\mathrm{S}^{6+}, \mathrm{P}^{5+}$ are the position of X. Considering the arid climate, the underground water became acid, making sulfide, especially pyrite, oxidize to form jarosite. The interference color of lenticular jarosite under plane polarized light and cross-polarized light was light yellow green (Fig. 3a, b, c), and its reflected color was bright yellow (Fig. 3d), making it easy to identify.

In the FESEM, it can be observed that the banded jarosite is made up of cubic and octahedron jarosite (Fig. 31). The orthoclase in the shale or the tephra is covered by cubic jarosite (Fig. 3e), which makes the plane polarized light and cross-polarized light of orthoclase to become yellow green (Fig. 3e) and its reflected light to become bright yellow (Fig. 3c, d). Most of the jarosite was transformed from framboidal pyrite as proved by EDS data (Table 3). This type of jarosite can be referred as originally framboidal pyrite pseudocrystal (FPP). A little jarosite exists in the form of coating on the organic matter (Fig. 3k). 
Table 2 TOC and XRD data of organic-rich shale in the Chang 7 member

\begin{tabular}{|c|c|c|c|c|c|c|c|c|}
\hline Sample & Lithology & TOC, wt $\%$ & Quartz, wt $\%$ & Orthoclase, wt $\%$ & $\begin{array}{l}\text { Plagio- } \\
\text { clase, wt } \%\end{array}$ & Jarosite, wt $\%$ & Clay, wt\% & $\mathrm{I} / \mathrm{S}$, ratio \\
\hline YSC-51-123 & Shale & 18.80 & 34.9 & 1.2 & 4.5 & 14.6 & 44.8 & 35 \\
\hline YSC-51-108 & Shale & 24.80 & 50.2 & 1.4 & 10.5 & 11.9 & 26 & 50 \\
\hline YSC-51-48 & Shale & 14.10 & 25.0 & 3.7 & 14.9 & 6.9 & 49.5 & 15 \\
\hline YSC-51-44 & Shale & 21.30 & 38.5 & 4.1 & 7.2 & 10.4 & 39.8 & 20 \\
\hline YSC-51-42 & Shale & 18.10 & 69.0 & 4.2 & 5.5 & 6.4 & 14.9 & 20 \\
\hline YSC-51-31 & Shale & 24.80 & 32.8 & 2.9 & 8.5 & 13.7 & 42.1 & 20 \\
\hline YSC-51-10 & Shale & 14.70 & 23.7 & 11.1 & 6.7 & 7.4 & 51.1 & 25 \\
\hline YSC-42-10 & Shale & 10.70 & 37.8 & 2.6 & 11.7 & 4.4 & 43.5 & 35 \\
\hline YSC-38-22 & Shale & 8.72 & 21.1 & 1.4 & 5.4 & 7.4 & 64.7 & 25 \\
\hline YSC-33-5 & Shale & 1.42 & 36.6 & 0.8 & 4.7 & - & 57.9 & 20 \\
\hline YSC-31-2 & Shale & 16.40 & 30.8 & 2.3 & 9.2 & 17.1 & 40.6 & 20 \\
\hline YSC-29A-64 & Shale & 15.40 & 33.8 & 2.6 & 7.7 & 15.9 & 40 & 15 \\
\hline YSC-29A-19 & Shale & 14.80 & 30.3 & 1.0 & 4.0 & 17.1 & 47.6 & 20 \\
\hline YSC-22-1 & Shale & 13.60 & 24.3 & 1.6 & 10.8 & 18.4 & 44.9 & 25 \\
\hline YSC-18-14 & Shale & 10.50 & 32.6 & 2.2 & 11.1 & 14.8 & 39.3 & 20 \\
\hline YSC-18-3 & Shale & 7.65 & 43.0 & 14.9 & 7.7 & 3.6 & 30.8 & 25 \\
\hline
\end{tabular}

Most of the FPP was well preserved and displayed various morphologies, including normal framboidal pyrite (NFPP) (Fig. 4a, b, c), tiny framboidal pyrite (TFPP) (Fig. 4a), larger infilled framboidal pyrite pseudocrystal (IFPP) (Fig. 4b), pyrite aggregation (PPA) (Fig. 4f), euhedral pyrite (EPP) (Fig. 4e) and amorphous pyrite (APP) (Fig. 4d). The average diameter of NFPP is from 6.2 to $11.9 \mu \mathrm{m}$. The standard deviation ranges from 1.4 to 2.26. The maximum size of framboids is from 11.7 to $25.2 \mu \mathrm{m}$ (Table 1). Vertically, the size distribution histogram of some of the samples with various TOC values is illustrated in Fig. 5.

\subsection{Features of volcanic ash interval}

More than 156 layers of ash have been identified in the Yishicun outcrop. The type of volcanic ash is mainly crystal tuff, some of which had developed graded lamination. Also, vitric tuff contains chicken bones and vitreous arc-shaped fragments (Fig. 6d, e). The crystals in the ash with grading lamination (Fig. 6a, b) are angular and sub-angular, and the grain sorting is medium to good. Vertically, most of the tuff intervals were developed at the middle and upper parts of the Yishicun outcrop (Fig. 2). Tuffaceous fine-grained sandstone (Fig. 6c) was developed in the lower part of the outcrop, and its grain sorting was relatively poor.

On the microscale, there is abundant volcanic ash in the organic-rich shale, and the occurrences of ash are mainly lenticular (Fig. 6g, h, i). Due to weathering, the feldspar in the ash is covered by cubic jarosite (Fig. 4h), and the interference color of feldspar turns to green yellow and the reflected light is bright yellow, which makes the crystal volcanic ash easily identified under reflected light.

\subsection{Estimation of ash content in organic-rich shale}

Based on the petrological research on organic-rich shale and volcanic ash, it has been found that the ash content is easily identified under reflected light due to cubic jarosite and $\mathrm{Fe}$ rich matrix. Also, as compared to the small and spherical felsic minerals from terrigenous input, the crystals in the ash are rather large and angular. All the samples selected to estimate the ash content were mainly from the upper part of the Yishicun outcrop to get rid of interference such as redox conditions.

Consequently, by combining all the features of ash intervals in the organic-rich shale, the ash content has been estimated based on a total of 704 observations under the polarizing microscope. It is proposed that with an increase in the ash content in the shale, TOC shows a gradual increase at first, then reaches a maximum when the ash content is about $6 \%$ and decreases later (Fig. 7).

\section{Discussion}

\subsection{Petrological features of organic-rich shale}

\subsubsection{Quartz and feldspar}

Banded quartz is usually interbedded with clay minerals, and organic-rich shale is rich in volcanic ash. 

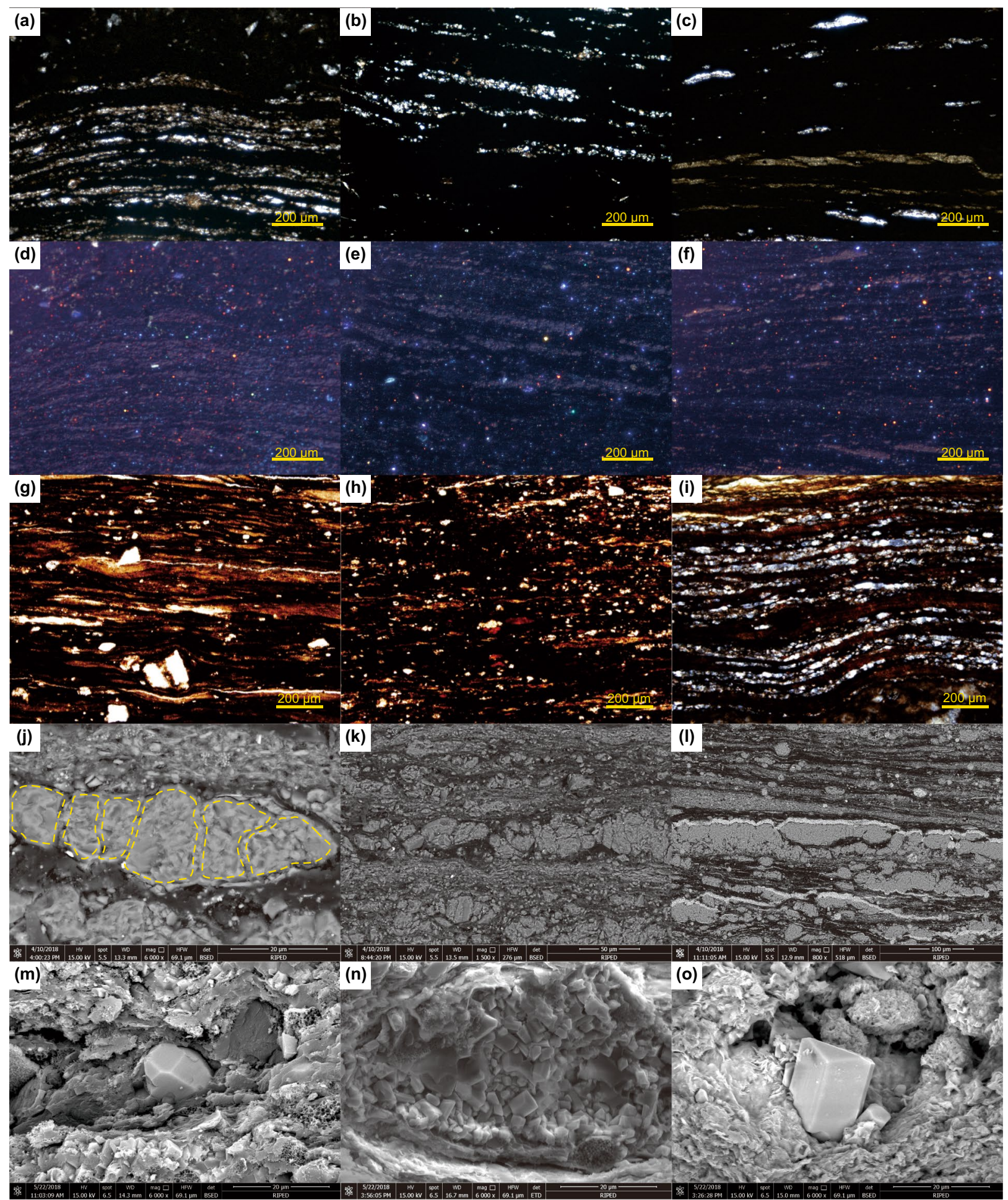

Fig. 2 Felsic minerals feature in organic-rich shale in the Chang 7 member a stripe quartz in sample YSC-29a-64 (plane polarized light), b stripe quartz in sample YSC-51-44 (plane polarized light), c lenticular quartz in sample YSC-18-6 (plane polarized light), d stripe quartz (in brown), orthoclase (in blue) and plagioclase (in yellow and green) (CL) in sample YSC-29a-64, e stripe quartz (in brown), orthoclase (in blue) and plagioclase (in yellow and green) (CL) in sample YSC-51-44, $\mathbf{f}$ stripe quartz (in brown), orthoclase (in blue) and plagioclase (in yellow and green) (CL) in sample YSC-18-6, $\mathbf{g}$ crystal fragment (larger and angular shape) and felsic mineral (smaller), h felsic mineral randomly distributed, $\mathbf{i}$ stripe-like quartz in sample YSC-29a-64, j quartz aggregation (backscattered electron), $\mathbf{k}$ stripe-like quartz (backscattered electron), $\mathbf{l}$ stripe quartz (backscattered electron), $\mathbf{m}$ authigenic quartz in sample YSC-51-48 (secondary electrons), $\mathbf{n}$ clustered authigenic orthoclase in sample YSC-31-2 (secondary electrons), o authigenic orthoclase in sample YSC-33-5 (secondary electrons) 

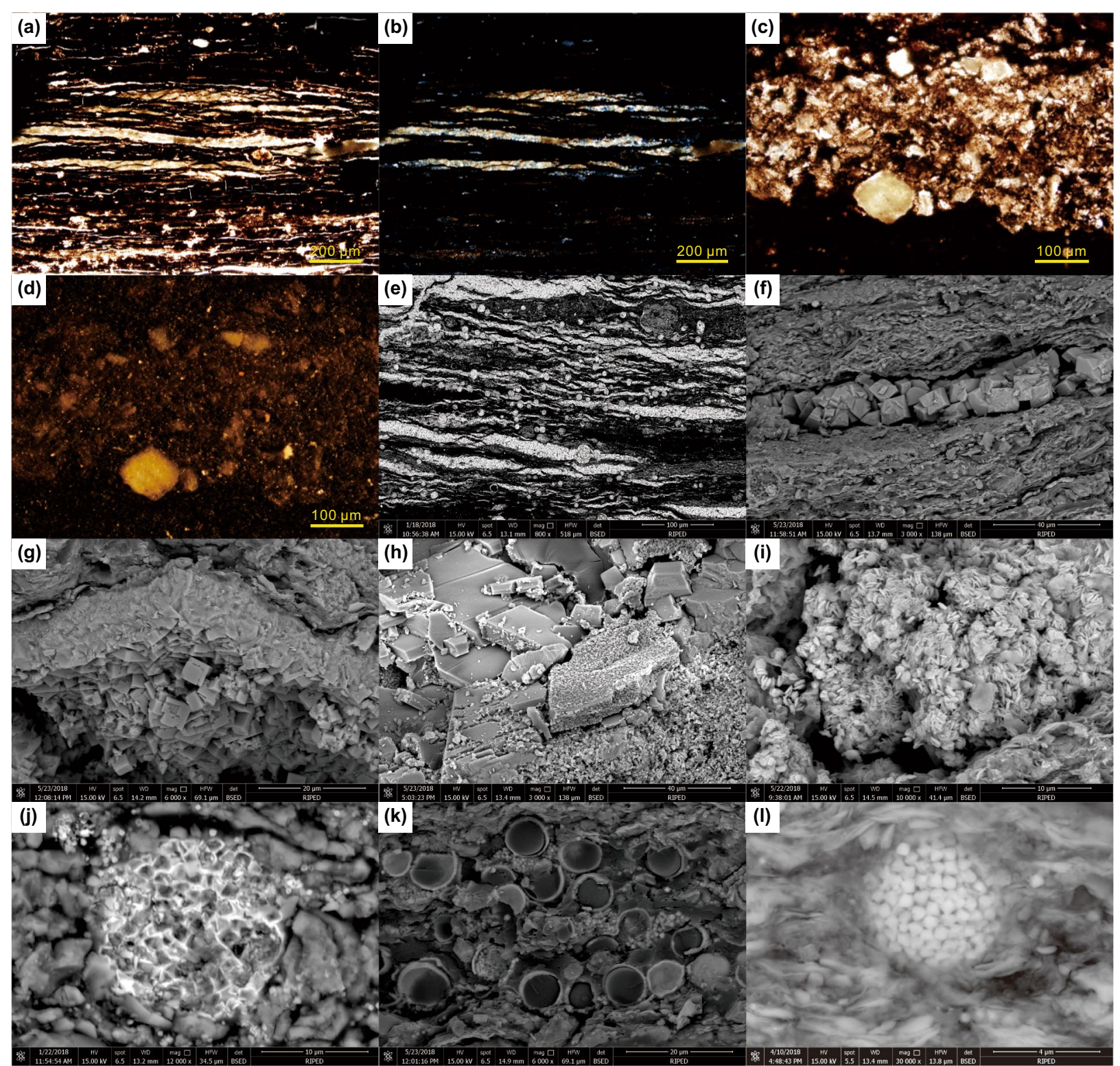

Fig. 3 Occurrence of jarosite in the organic-rich shale in Chang 7 member a stripe jarosite in sample YSC-51-108 (plane polarized light), b stripe jarosite in sample YSC-51-108 (cross-polarized light), $\mathbf{c}$ ash interval in shale in sample YSC-22-1 (cross-polarized light), d ash interval in shale in sample YSC-22-1 (reflected light), e stripe and sphere jarosite (in light gray) in sample YSC-51-48 (backscattered electron), f cubic jarosite in crack in sample YSC-33-5 (secondary electrons) (backscattered electron), $\mathbf{g}$ cubic jarosite in the crack (secondary electrons), $\mathbf{h}$ cubic jarosite covers the feldspar (secondary electrons), $\mathbf{i}$ flaky-shaped jarosite in the pore (secondary electrons), $\mathbf{j}$ framboidal pyrite pseudocrystal remnant in sample YSC-51-42 (backscattered electron), $\mathbf{k}$ jarosite coat of organic matter in sample YSC-51-82 (backscattered electron), $\mathbf{l}$ framboidal pyrite pseudocrystal in sample YSC-29A-19 (backscattered electron)

Consequently, the formation of irregular quartz is likely to be associated with the release of siliceous material. The source of siliceous material mainly includes the transformation of clay minerals and the vitrification of volcanic ash. Based on the XRD data (Table 2), the illite-to-smectite ratio is between $15 \%$ and $45 \%$, indicating a middle diagenetic stage $\mathrm{A}$, and the corresponding paleo-geotemperature is generally between 85 and $140{ }^{\circ} \mathrm{C}$. Under these conditions, the transformation of montmorillonite to illite can provide silica for the formation of quartz.

The CL color of quartz is brown indicating that the origin of quartz is from the regional metamorphic rocks, which is consistent with the previous results obtained from the southern part of the Ordos basin (Fan 2010). Consequently, the quartz in the shale is mainly from terrigenous input and converted into banded quartz aggregation by diagenesis. This possibly indicates that the water depth of this region was 
Table 3 EDS data of jarosite (atomic ratio)

\begin{tabular}{llllll}
\hline Sample & O & Fe & S & K & Na \\
\hline YSC-51-33 & 61.98 & 20.92 & 13.6 & 3.5 & - \\
& 67.35 & 18.51 & 10.57 & 3.57 & - \\
YSC-51-48 & 23.56 & 41.35 & 30.13 & 4.96 & - \\
& 55.71 & 28.46 & 10.61 & 5.23 & - \\
YSC-51-5 & 57.42 & 27.59 & 9.76 & 5.23 & - \\
& 65.75 & 34.25 & - & - & - \\
YSC-51-42 & 40.55 & 59.45 & - & - & - \\
& 66.88 & 19.1 & 12 & 2 & - \\
& 44.95 & 29.55 & 21.2 & 4.3 & - \\
& 63.92 & 36.08 & - & - & - \\
& 70.98 & 18.36 & 7.5 & 4.15 & - \\
YSC-29A-64 & 77.79 & 19.13 & 10.02 & 3.06 & - \\
& 79.54 & 12.04 & 7.03 & 0.94 & 1.99 \\
& 70.76 & 17.22 & 7.45 & 0.92 & 1.86 \\
YSC-33-5 & 76.89 & 12.27 & 7.5 & 3.34 & - \\
& 74.91 & 13.21 & 8 & 3.88 & - \\
& 29.82 & 40.87 & 20.4 & 8.92 & - \\
& 32.48 & 40.33 & 21.66 & 2.97 & 2.55 \\
YSC-51-58 & 64.81 & 18.89 & 11.94 & 4.39 & - \\
YSC-48-4 & 78.66 & 10.55 & 7.56 & 3.23 & - \\
& 60.76 & 21.08 & 13.38 & 4.48 & 0.3 \\
\hline
\end{tabular}

relatively shallow and the shale deposits were near a terrigenous province, which was also proved by the ratios of $\mathrm{Al} / \mathrm{Si}$ and $\mathrm{Si} /(\mathrm{Si}+\mathrm{Al}+\mathrm{Fe})(\mathrm{Li}$ et al. 2018). Some authigenic feldspars (Fig. 3n, o) developed in the samples of YSC-33-5 and YSC-31-2, which suggests that there could probably have been hydrothermal activity in the Chang 7 period (Xiao et al. 2001; He et al. 2016).

\subsubsection{Jarosite}

Based on EDS data (Table 3), it is clear that the contents of $\mathrm{K}$ and $\mathrm{O}$ are relatively lower than the general chemical formula, which means that the pyrite has not completely transformed to jarosite. Most samples are in the transition state from pyrite to jarosite. However, some of them were thoroughly decomposed and turned into iron oxides and the morphological features of framboidal pyrite can no longer be recognized (Fig. 3j).

\subsection{The relationship between ash content and enrichment of organic matter}

Volcanic ash is well developed in numerous high-quality source rocks, such as the Silurian Longmaxi Formation, the Permian Lucaogou Formation, the Triassic Yanchang Formation (Qiu et al. 2009) and the Cretaceous Eagle Ford and

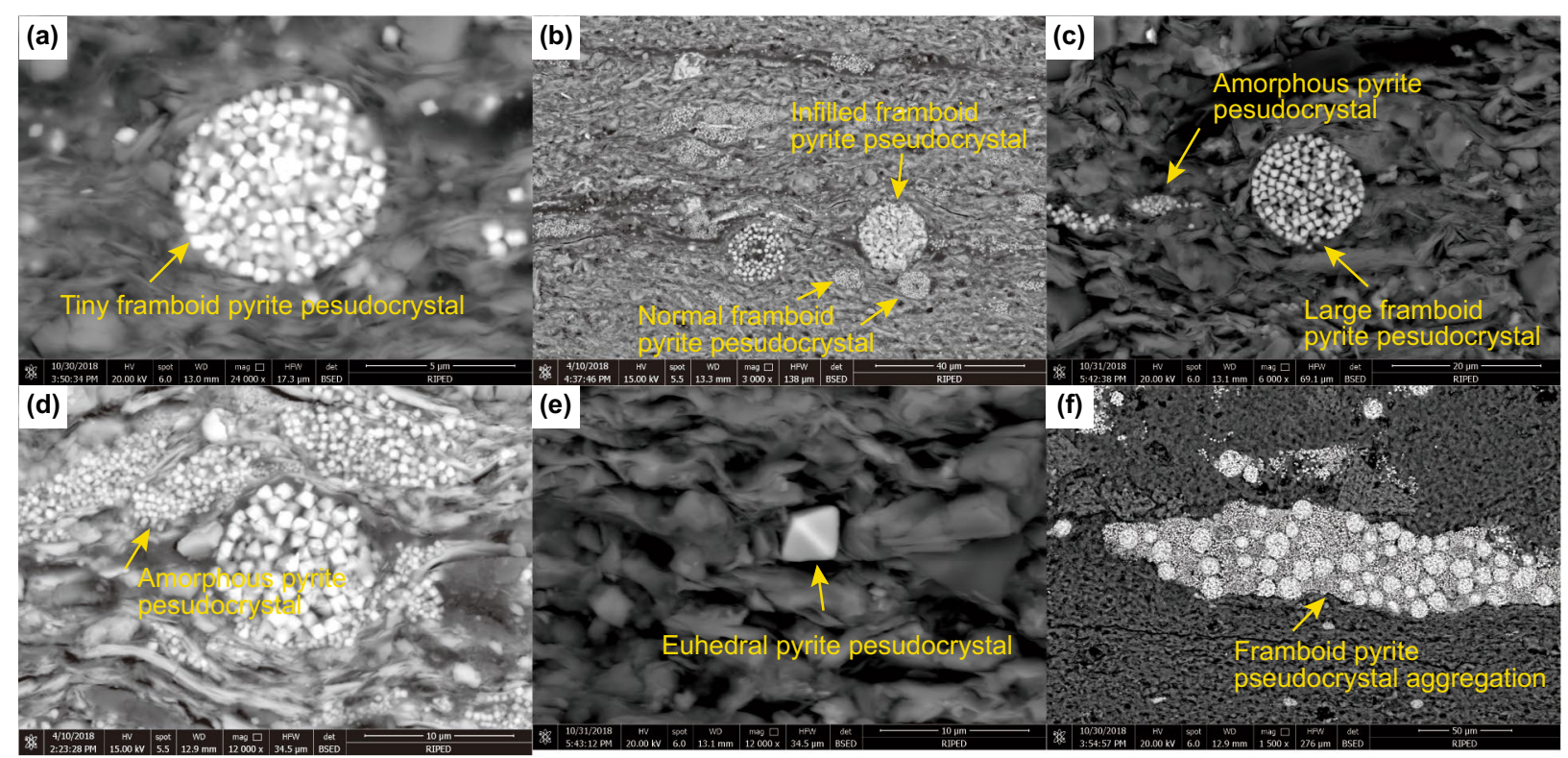

Fig. 4 Occurrence of framboidal pyrite pseudocrystal under the FESEM (backscattered electron) a tiny framboidal pyrite pseudocrystal (6.3 $\mu \mathrm{m}$ in diameter) in sample YSC-51-31, $\mathbf{b}$ infilled framboidal pyrite pseudocrystal with bigger size compared to the normal framboidal pyrite pseudocrystal, $\mathbf{c}$ large framboidal pyrite pseudocrystal in sample YSC18-14, d amorphous pyrite pseudocrystal with different size in sample YSC-5182 , e euhedral pyrite pseudocrystal in sample YSC-42-10, f pyrite framboid pseudocrystal aggregation in sample YSC-18-3 


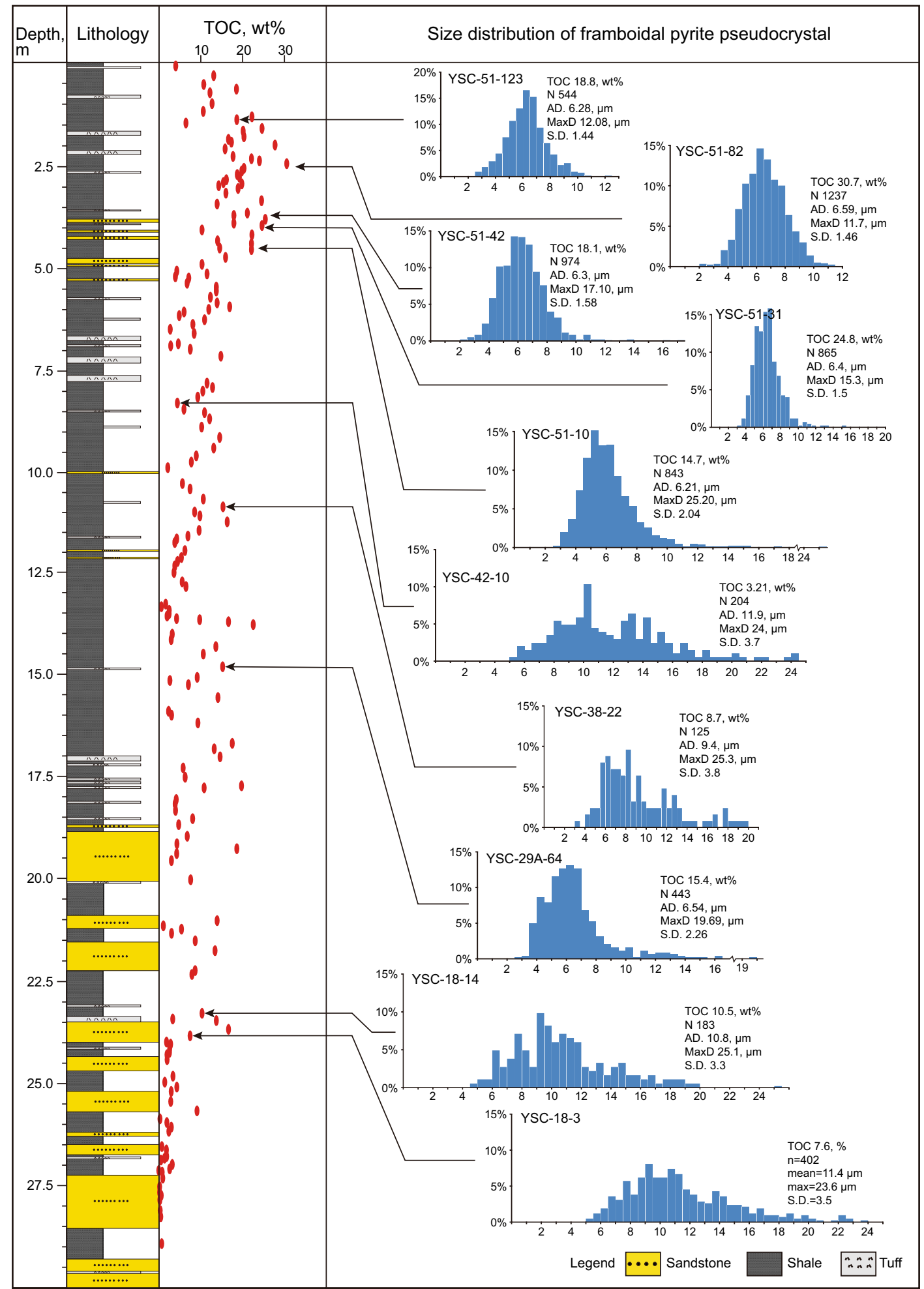

Fig. 5 Size distribution of pyrite framboid pseudocrystal in organic-rich shale in Chang 7 member

Currently, the studies on the effect of ash on algal blooms follow two strategies. One is to track modern volcanic ash movement in the atmosphere and the other is to measure the changes in the amount of chlorophyll indirectly by remote sensing in the ocean where the sea area is under the influence of volcanic ash. Some studies found that the content of chlorophyll a was 2-5 times the background value after the volcanic ash fell into water, and $\mathrm{Fe}, \mathrm{P}$ were the key elements 


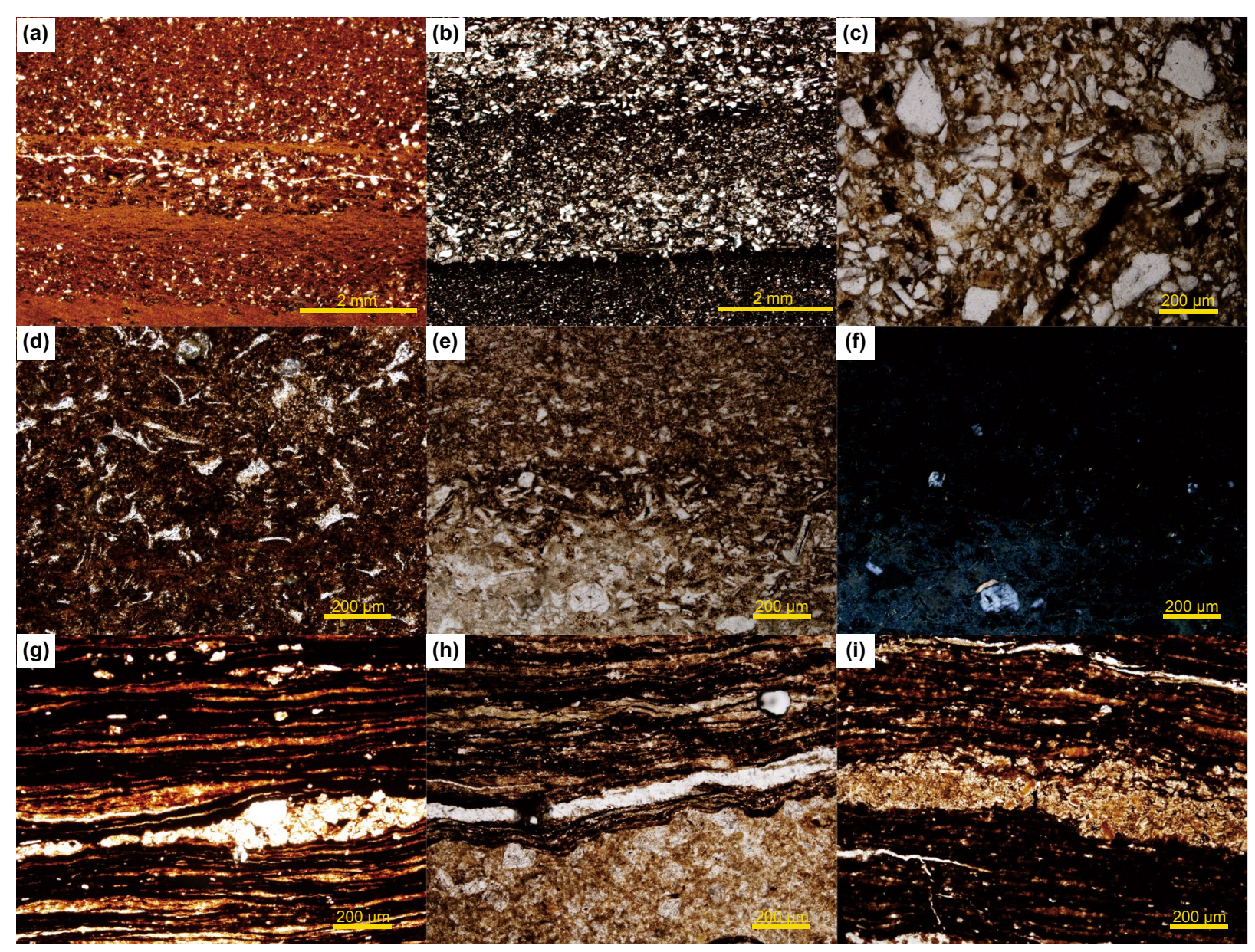

Fig. 6 Petrological features of volcanic ash intervals in organic-rich shale a crystal tuff with graded bedding in sample YSC-33-6 (plane polarized light), b crystal tuff with graded bedding in sample YSC-49-18 (plane polarized light), c tuffaceous sandstone in sample YSC-18-6 (plane polarized light), d vitric tuff in sample YSC-51-93 (plane polarized light), e vitric tuff in sample YSC-34-9 (plane polarized light), f crystal tuff interlayer in sample YSC-51-10 (plane polarized light), $\mathbf{g}$ vitric tuff in sample YSC-34-9 (cross-polarized light), $\mathbf{h}$ vitric tuff interlayer in sample YSC-29A-26 (plane polarized light), $\mathbf{i}$ crystal tuff interlayer in sample YSC-22-1 (plane polarized light)

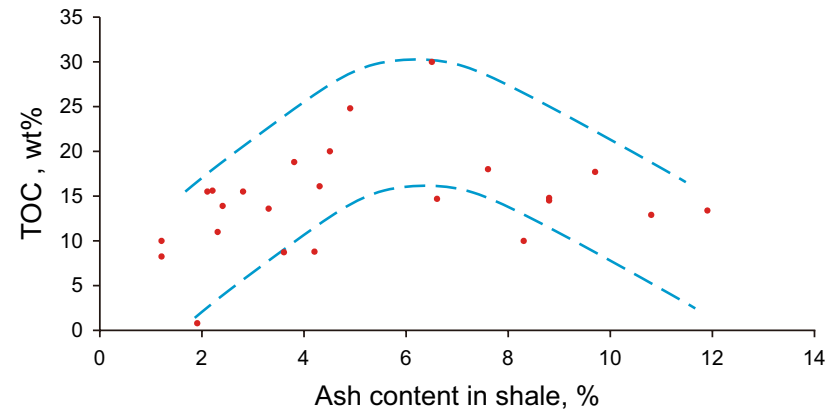

Fig. 7 Relationship between the content of ash and TOC in organicrich shale

for this phenomenon (Lin et al. 2011). Fe is a vital element to synthetize chlorophyll synthetase in algae, and the content of this enzyme has a direct impact on the primary productivity in the ocean (Langmann et al. 2010).
Another approach is to do laboratory experiments. The results demonstrated that the content of chlorophyll a in diatoms was three times more than the matching group with the addition of a small amount of Fe, indicating a significant improvement in the photosynthetic efficiency (Duggen et al. 2007). Based on the studies of volcanic intervals in the Eagle Ford Formation (Lee et al. 2018), researchers estimated that the contribution of Fe from volcanic eruptions in the Cretaceous is ten times more than that of the total input of $\mathrm{Fe}$ to the modern ocean. After ash falls into water, $75 \%$ of $\mathrm{Fe}$, $\mathrm{P}$ and $\mathrm{Si}$ in the volcanic ash releases into sediment, which leads to large amounts of nutrients and improves the primary productivity.

Pioneer studies based on the geochemistry of volcanic ash in the Chang 7 member (Zhang et al. 2008, 2009; Qiu et al., 2011) showed that the Fe content in the volcanic ash of the Chang 7 member is relatively high. In addition, volcanic ash deposits are widely distributed in the lacustrine 


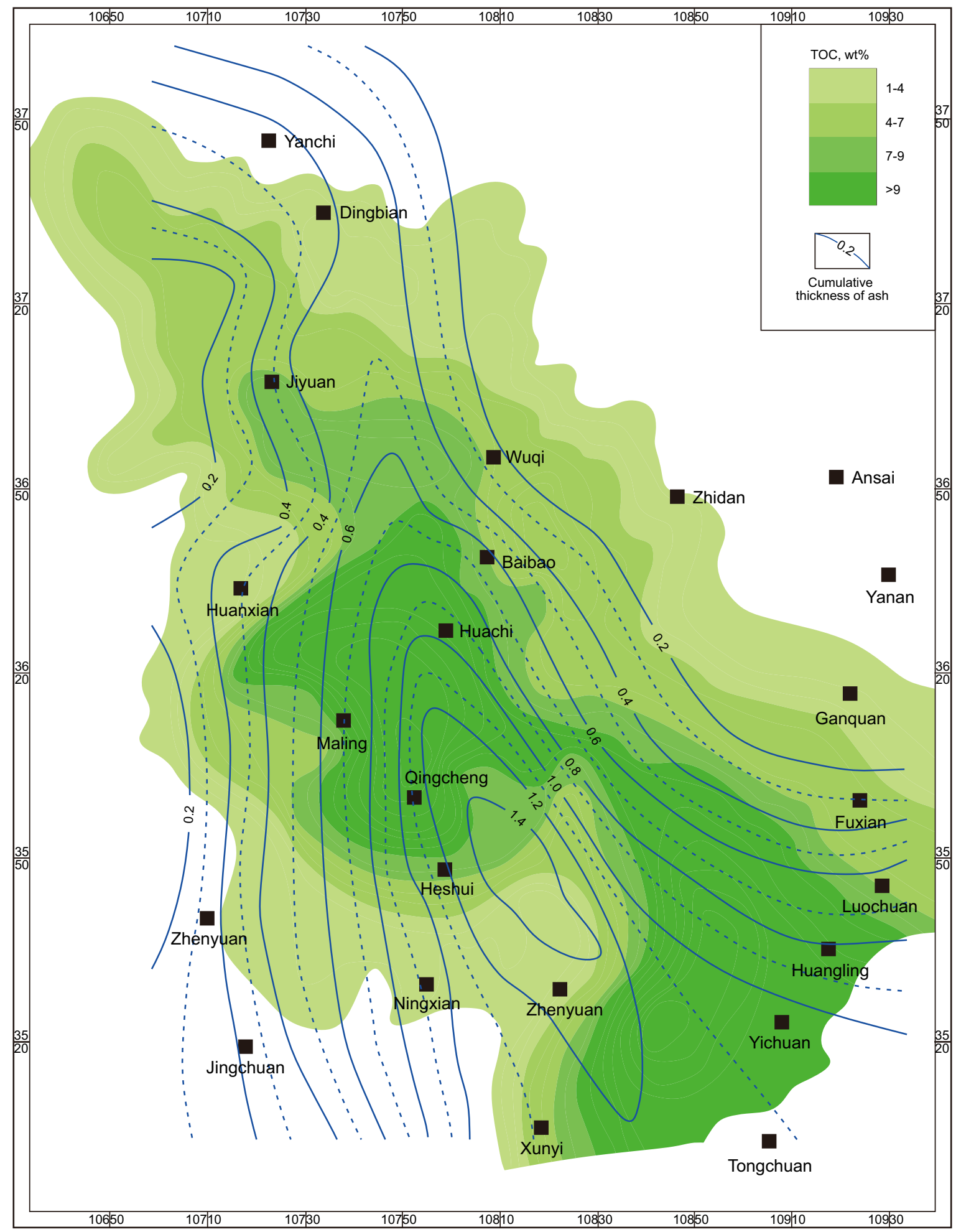

Fig. 8 Distribution of ash thickness and TOC of organic-rich shale in the Chang 7. Modified from Qiu (2008)

sediments (Fig. 6), and they became thinner from southeast to northwest. It is generally believed that the volcanic ash has a positive influence on the enrichment of organic matter in the source rock due to the uniform spatial distribution of ash and source rock (Li 2007; Li 2009; Qiu 2011). Although the TOC of the Chang 7 member source rock is relatively high in the ash distribution area, the abundance of organic matter of the source rock of the Chang 7 member is not the 
highest in the north of Zhenyuan area where there is the largest thickness of tuff (Fig. 8). The good-quality source rock with the highest TOC, however, developed in the area where the cumulative thickness of tuff is less than $1.2 \mathrm{~m}$. This could be probably due to that the volcanic ash deposit in water releases heavy metal elements such as $\mathrm{Cu}, \mathrm{Cd}, \mathrm{Pb}$ and $\mathrm{Zn}$ (Duggen et al., 2007). Excessive tuff input to the lake would lead to a catastrophe in paleo-lake ecosystems (Zhang et al. 2011).

Although our method mentioned above has some defects in estimating the ash content in the shale, the enrichment of organic matter is controlled by multiple factors rather than just a single factor, which is the reason that the data points are still relatively dispersed (Fig. 7). Nevertheless, the increasing and decreasing tendency is still clear, which provides the evidence of the dual effects of ash on the enrichment of organic matter.

\subsection{The relationship between oxygen level and enrichment of organic matter}

Framboidal pyrite is aggregated spherical microcrystal pyrite, and the diameter distribution of framboidal pyrites is reliable evidence to judge the redox level of the water column (Wilkin et al. 1996; Wilkin and Barnes 1997; Wei et al. 2015).

In an anoxic water body, the diameter of framboidal pyrites is relatively small which is about $5.0 \pm 1.7 \mu \mathrm{m}$ (Wilkin and Barnes 1997), whereas when the redox level is low and the redox boundary is below the sediment-water interface, larger sulfidic particles can develop, and the diameters are about $7.7 \pm 4.1 \mu \mathrm{m}$ (Wilkin and Barnes 1997). The maximum diameter and standard deviation of the framboids increase proportionately with an increase in the oxygen content in the water column (Wignall and Newton 1998). This can assist in evaluating the redox level in the water column (Wignall and Newton 1998).

Some studies (Luning et al. 2003; Wignall et al. 2010) have proposed that due to weathering, pyrite is easily destroyed in outcrops. The morphological features of pyrite, however, were still recorded by the framboid remnants, such as iron oxide or jarosite, and still are a reliable proxy to signify the redox of a waterbody as long as the shape of the pyrite framboid pseudocrystal was not destroyed. Consequently, the diameter distribution and the abundance of pseudocrystal framboids are still considered to be effective tools to evaluate the redox level of the water body.

The pyrite that forms in the water column is syngenetic pyrite, whereas in the sediment it is diagenetic pyrite. The TFPP is smaller in size which indicates a syngenetic origin under an anoxic environment, whereas large framboidal pyrite pseudocrystal (Fig. 5c) and PPA indicate a diagenetic origin in a dysoxic-oxic environment. The EPP and APP are formed in the sediment during early diagenesis. IFPP is transformed from NFPP, which indicates a secondary growth in the sediment and cannot be measured.

In the Yishicun outcrop, the diameter of all the NFPP pseudocrystals is greater than $6 \mu \mathrm{m}$ and some are more than $10 \mu \mathrm{m}$. The cross-plots of mean diameter-standard deviation and mean average-skewness are used to distinguish the euxinic and dysoxic water. From these plots, it is clear that most of the points are located near the threshold and some are far from it (Fig. 9). By combining the relationship between the oxygen level and pyrite diameter (Table 4), it is concluded that the water body in the Chang 7 period was dysoxic to anoxic, and intermittently oxic. In other words, the water redox level at that time was not high enough to be euxinic and there was no water stratification.

In the upper part of the Yishicun outcrop (Fig. 2), samples (YSC-51-123, YSC-51-82, YSC-51-42 and YSC51-31) with relatively high TOC show a normal size distribution. The average diameter is about $6 \mu \mathrm{m}$, and the standard deviation is 1.5 , illustrating that the particle size distribution is relatively concentrated and the oxygen content in water was relatively low and the water body was dysoxic-anoxic. On the contrary, in the middle part of the outcrop, for samples such as YSC-38-22 and YSC29A-64, the average diameter and standard deviation are much larger and the size distribution is much more scattered. For the lower part of the outcrop, the TOC values of the samples such as YSC-18-14 and YSC-18-3 are less than $10 \%$, and the average diameter and standard deviation are more than $10 \mu \mathrm{m}$ and 3 , respectively, which means that the oxygen content in the water was higher.

The sedimentary environment of the Chang 7 member in Tongchuan is also demonstrated by means of sulfur isotope data and organic geochemical index. The $\delta^{34} \mathrm{~S}_{\mathrm{py}}$ fluctuates significantly, being lighter in shale with high TOC and heavier in mudstone with low TOC (Wang et al. 2017), which demonstrates that the shale with high TOC deposited in reducing conditions. The contents of phytane $(\mathrm{Ph})$ and pristine $(\mathrm{Pr})$ are usually related to the redox conditions during sedimentation, and the $\mathrm{Pr} / \mathrm{Ph}$ ratio is a sensitive indicator of the redox conditions which range from 0.39 to 0.60 , indicating reducing conditions ( $\mathrm{Li}$ et al. 2017). Additionally, the discrimination diagram of redox conditions $(\mathrm{V} / \mathrm{Cr}$ and $\mathrm{V} /(\mathrm{V}+\mathrm{Ni})$ ) suggested a dysoxic-toanoxic bottom water environment (Li et al. 2018). Accordingly, it is clear that the redox conditions in the water body have a positive impact on the enrichment of organic matter (Fig. 10) and the sedimentary environment in the Chang 7 period was mainly dysoxic-anoxic and oxic intermittently. 

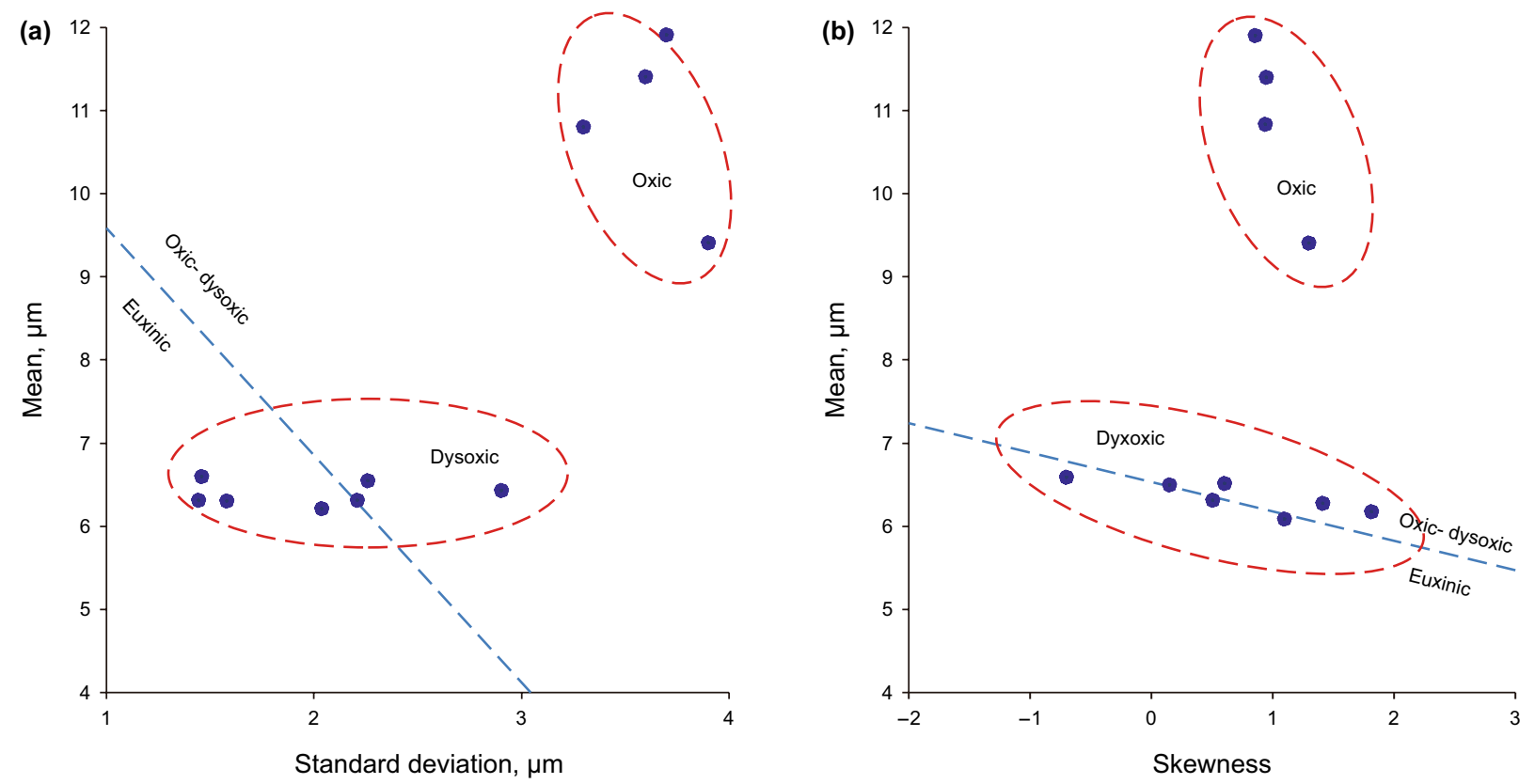

Fig. 9 a Mean diameter versus standard deviation of the size distributions of framboidal pyrite pseudocrystal $\mathbf{b}$ mean versus skewness of framboidal pyrite pseudocrystal size distributions. The line represents the boundary between euxinic and oxic-dysoxic environments (according to Wilkin et al. 1996)

Table 4 Sedimentary environment and the diameter and morphology of pyrite

\begin{tabular}{|c|c|c|c|}
\hline Conditions & Oxygen level (C) & Framboid parameters & Typical picture of pyrite \\
\hline Euxinic (persistently sulfidic) & $\begin{array}{l}\mathrm{C}<0.2 \mathrm{~g} / \mathrm{L} \\
\left(\text { free } \mathrm{H}_{2} \mathrm{~S}\right)\end{array}$ & $\begin{array}{l}\text { Tiny size }(3-5 \mu \mathrm{m} \text { average }) \text {, abundant, with } \\
\text { lower standard deviation. } \\
\text { Framboids dominate }\end{array}$ & \\
\hline $\begin{array}{l}\text { Anoxic (no oxygen in bottom waters for long } \\
\text { period) }\end{array}$ & $\begin{array}{l}\mathrm{C}<0.2 \mathrm{~g} / \mathrm{L} \\
\left(\text { no free } \mathrm{H}_{2} \mathrm{~S}\right)\end{array}$ & $\begin{array}{l}\text { Small size ( } 4-6 \mu \mathrm{m} \text { in average), abundant, with } \\
\text { relatively lower standard deviation } \\
\text { Framboids dominate }\end{array}$ & \\
\hline $\begin{array}{l}\text { Lower dysoxic (weakly oxygenated bottom } \\
\text { water) }\end{array}$ & $0.2 \mathrm{~g} / \mathrm{L}<\mathrm{C}<2 \mathrm{~g} / \mathrm{L}$ & $\begin{array}{l}\text { Media size ( } 6-10 \mu \mathrm{m} \text { in average), with a few } \\
\text { framboids and crystalline pyrite }\end{array}$ & \\
\hline $\begin{array}{l}\text { Upper dysoxic (partial oxygen restriction in } \\
\text { bottom water) }\end{array}$ & & $\begin{array}{l}\text { Major of pyrite as discrete crystals, relatively } \\
\text { higher standard deviation, little propor- } \\
\text { tion }<5 \mu \mathrm{m}\end{array}$ & \\
\hline Oxic (no oxygen restriction) & $\mathrm{C}>2 \mathrm{~g} / \mathrm{L}$ & No framboidal pyrite & - \\
\hline
\end{tabular}




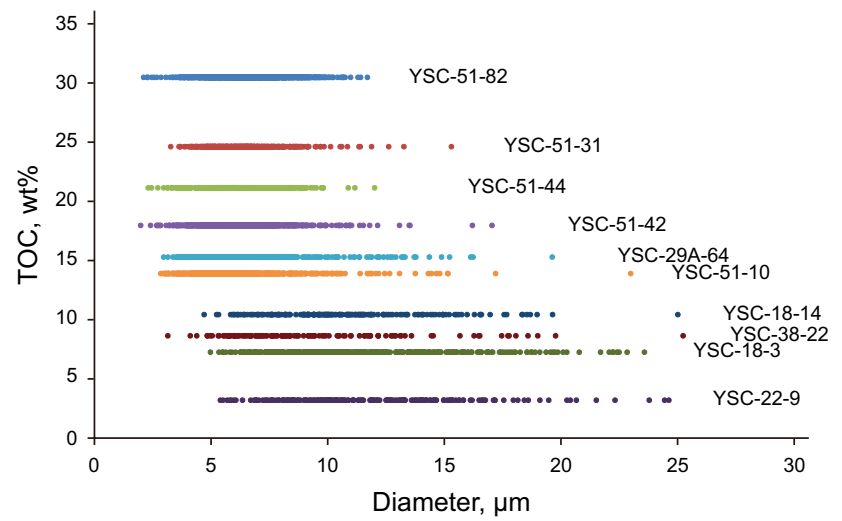

Fig. 10 Relationship between FPP distribution and TOC of organicrich shale in Chang 7 member

\section{Conclusions}

Based on the petrological analysis of the organic-rich shale, the estimation of ash content and measurements of framboidal pyrite pseudocrystal in the Yishicun section, several conclusions can be drawn.

The major composition of organic-rich shale is quartz, feldspar, jarosite and clay minerals. Most of the felsic minerals are from terrestrial input and volcanic ash. The identification of authigenic feldspar probably indicates hydrothermal activities.

The volcanic ash in the shale has a dual effect on the enrichment of organic matter. When the ash content in the shale is about $6 \%$, the ash makes a meaningful contribution to the enrichment of organic matter in the shale. When the content is lower than this threshold value, TOC increases with an increase in the ash content. However, when the ash content is over the threshold, TOC decreases with an increase in the ash content.

A reducing water body has a positive impact on the accumulation of organic matter. Based on the morphological studies of framboidal pyrite pseudocrystal, it is clear that with a decrease in the oxygen content in the water column, the TOC of the shale shows an increasing trend.

Open Access This article is distributed under the terms of the Creative Commons Attribution 4.0 International License (http://creativeco mmons.org/licenses/by/4.0/), which permits unrestricted use, distribution, and reproduction in any medium, provided you give appropriate credit to the original author(s) and the source, provide a link to the Creative Commons license, and indicate if changes were made.

\section{References}

Betts JN, Holland HD. The oxygen content of ocean bottom waters, the burial efficiency of organic carbon, and the regulation of atmospheric oxygen. Glob Planet Change. 1991;97(5):5-18. https://doi. org/10.1016/0921-8181(91)90123-E.

Cui JW, Zhu RK, Luo Z, et al. Sedimentary and geochemical characteristics of the Triassic Chang 7 member shale in the southeastern Ordos basin, central China. Pet Sci. 2019;16(2):285-97. https:// doi.org/10.1007/s12182-019-0307-9.

Demaison GJ, Moore GT. Anoxic environments and oil source bed genesis. Org Geochem. 1980;2(1):9-31. https://doi. org/10.1016/0146-6380(80)90017-0.

Duggen S, Croot P, Schacht U, et al. Subduction zone volcanic ash can fertilize the surface ocean and stimulate phytoplankton growth: evidence from biogeochemical experiments and satellite data. Geophys Res Lett. 2007;34(1):95-119. https://doi. org/10.1029/2006GL027522.

Er C, Zhao JZ, Wang R, et al. Controlling role of sedimentary environment on the distribution of organic-rich shale: a case study of the Chang 7 member of the Triassic Yanchang Formation: Ordos basin. Nat Gas Geosci. 2015;26(5):823-32. https://doi. org/10.11764/j.issn.1672-1926.2015.05.0823.

Fan MM. Research on sedimentary facies of Yanchang Formation in the southwest of Ordos basin (master dissertation). Xi'an: Northwest University; 2010 (in Chinese).

Fu JH, Deng XQ, Chu MJ, et al. Features of deepwater lithofacies, Yanchang Formation in Ordos basin and its petroleum significance. Acta Sedimentol Sin. 2013;31(5):928-38. https://doi. org/10.14027/j.cnki.cjxb.2013.05.011 (in Chinese).

$\mathrm{He}$ C, Ji LM, Wu YD, et al. Characteristics of hydrothermal sedimentation process in the Yanchang Formation, south Ordos basin, China: evidence from element geochemistry. Sediment Geol. 2016;345:33-41. https://doi.org/10.1016/j.sedgeo.2016.09.001.

He C, Ji LM, Su A, et al. Source-rock evaluation and depositional environment of black shales in the Triassic Yanchang Formation, southern Ordos basin, north- central China. J Pet Sci Eng. 2019;173:899-911. https://doi.org/10.1016/j.petro 1.2018.10.089.

Katz BJ. Controlling factors on source rock development- a review of productivity, preservation, and sedimentation rate. SEPM. 2005. https://doi.org/10.2110/pec.05.82.0007.

Langmann B, Zakšek K, Hort M, et al. Volcanic ash as fertiliser for the surface ocean. Atmos Chem Phys. 2010;10(8):3891-9. https ://doi.org/10.5194/acp-10-3891-2010.

Lee CTA, Jiang H, Ronay E, et al. Volcanic ash as a driver of enhanced organic carbon burial in the cretaceous. Sci Rep. 2018;8(1):41-97. https://doi.org/10.1038/s41598-018-22576-3.

Lei Y, Feng QL, Gui BW. Geobiological model for organic enrichment in upper Permian Dalong Formation of Qingdingshan section at Chaohu. Anhui J Palaeogeogr. 2010;12(2):202-11 (in Chinese).

Li DL, Li RX, Zhu Z, et al. Origin of organic matter and paleosedimentary environment reconstruction of the Triassic oil shale in Tongchuan city, southern Ordos basin (China). Fuel. 2017;208(15):223-35. https://doi.org/10.1016/j.fuel.2017.07.008.

Li DL, Li RX, Tao X, et al. Characteristic and geological implications of major elements and rare earth elements of Triassic Chang 7 oil shale in Tongchuan city, southern Ordos basin (China). Minerals. 2018;8(4):157. https://doi.org/10.3390/min8040157.

Li YF, Shao DY, Lv HG, et al. A relationship between elemental geochemical characteristics and organic matter enrichment in marine shale of Wufeng Formation- Longmaxi Formation. Sichuan Basin Acta Pet Sin. 2015;36(12):1470-83. https://doi.org/10.7623/syxb2 01512002 (in Chinese). 
Li H. Research in characteristic of deep lacustrine sediment and tuff deposits of Yanchang Formation, upper Triassic in Ordos basin (master dissertation). Xi'an: Northwest University; 2009 (in Chinese).

Li Q. The radioactive anomaly in the deep strata and its impacts on source rocks' evolvement in southwest Ordos basin (mater dissertation). Xi' an: Northwest University; 2007 (in Chinese).

Lin II, Hu CM, Li YH, et al. Fertilization potential of volcanic dust in the low-nutrient low-chlorophyll western north pacific subtropical gyre: satellite evidence and laboratory study. Glob Biogeochem Cycles. 2011;25(1):73. https://doi.org/10.1029/2009GB003758.

Luning S, Kolonic S, Loydell DK, et al. Reconstruction of the original organic richness in weathered Silurian shale outcrops (Murzuq and Kufra basins, southern Libya). GeoArabia. 2003;8(2):299-308.

Ma ZH, Chen QS, Shi ZW, et al. Geochemistry of oil shale from Chang 7 reservoir of Yanchang Formation in south Ordos basin and its geological significance. Geol Bull China. 2016;35(9):1550-8 (in Chinese).

Meng QT, Liu ZJ, Hu F, et al. Productivity of eocene ancient lake and enrichment mechanism of organic matter in huadian basin. J China Univ Pet. 2012;36(5):38-44. https://doi.org/10.3969/j. issn.1673-5005.2012.05.007 (in Chinese).

Qiu XW. Characteristics and forming environments of tuffs in Yanchang Formaiton in Ordos basin (master dissertation). Xi'an: Northwest University; 2008 (in Chinese).

Qiu XW, Liu CY, Li YH, et al. Distribution characteristics and geological significances of tuff interlayers in Yanchang Formation of Ordos basin. Acta Sedimentol Sin. 2009;27(6):1138-46. https:// doi.org/10.14027/j.cnki.cjxb.2009.06.012 (in Chinese).

Qiu XW, Liu CY, Mao GZ, et al. Petrological- geochemical characteristics of volcanic ash sediments in Yanchang Formation in Ordos basin. Earth Sci J China Univ Geosci. 2011;36(1):139-50. https ://doi.org/10.3799/dqkx.2011.015 (in Chinese).

Qiu XW. Characteristics and dynamic settings of Yanchang period hydrocarbon-rich depression in Ordos basin, China (doctoral dissertation). Xi' an: Northwest University; 2011 (in Chinese).

Sun SS, Yao YB, Lin W. Elemental geochemical characteristics of the oil shale and the paleo-lake environment of the Tongchuan area, southern Ordos basin. Bull Mineral Pet Geochem. 2015;34(3):642-5. https://doi.org/10.3969/j.issn.10072802.2015.03.021 (in Chinese).

Tribovillard N, Algeo TJ, Lyons T, et al. Trace metals as paleoredox and paleoproductivity proxies: an update. Chem Geol. 2006;232(12):12-32. https://doi.org/10.1016/j.chemgeo.2006.02.012.

Wang C, Wang Q, Chen GJ, et al. Petrographic and geochemical characteristics of the lacustrine black shales from the upper Triassic Yanchang Formation of the Ordos basin, China: implications for the organic matter accumulation. Mar Pet Geol. 2017;86:52-65. https://doi.org/10.1016/j.marpetgeo.2017.05.016.

Wang L. The recovery of the paleoproductitivty in the period of Chang 7 in Ordos basin and its control factors (mater dissertation). Xi' an: Northwest University; 2015 (in Chinese).

Wang PJ, Gao YF, Cheng RH, et al. Description of Cretaceous sedimentary sequence of the second and third member of the Qingshankou Formation recovered by CCSD-SK-I south borehole in Songliao basin: lithostratigraphy, sedimentary facies and cyclic stratigraphy. Earth Sci Front. 2009;16(2):288-313. https://doi. org/10.1016/S1872-5791(08)60080-9.
Wei H, Algeo TJ, Yu H, et al. Episodic euxinia in the changhsingian (late Permian) of south China: evidence from framboidal pyrite and geochemical data. Sediment Geol. 2015;319(15):78-97. https ://doi.org/10.1016/j.sedgeo.2014.11.008.

Wignall PB, Newton R. Pyrite framboid diameter as a measure of oxygen deficiency in ancient mudrocks. Am J Sci. 1998;298(7):53752. https://doi.org/10.2475/ajs.298.7.537.

Wignall PB, Bond DPG, Kuwahara K, et al. An 80 million year oceanic redox history from Permian to Jurassic pelagic sediments of the mino-tamba terrane, sw Japan, and the origin of four mass extinctions. Glob Planet Change. 2010;71(1-2):109-23. https:// doi.org/10.1016/j.gloplacha.2010.01.022.

Wilkin RT, Barnes HL. Formation processes of framboidal pyrite. J Geochem Soc Meteorit Soc Geochim Cosmochim Acta. 1997;61(2):323-39. https://doi.org/10.1016/s0016 -7037(96)00320-1.

Wilkin RT, Barnes HL, Brantley SL, et al. The size distribution of framboidal pyrite in modern sediments: an indicator of redox conditions. Geochim Cosmochim Acta. 1996;60(20):3897-912. https ://doi.org/10.1016/0016-7037(96)00209-8.

Xiao RG, Zhang HC, Chen HQ, et al. Hydrothermal sedimentary rock and indicators of minerals and rocks. Earth Sci Front. 2001;8(04):379-85. https://doi.org/10.3321/j.issn:10052321.2001.04.018 (in Chinese).

Xiong LF, Liu CY, Qiu XW, et al. Tectonic activity of late Triassic in Ordos basin and its effect on the formation of high quality source rocks. Geol Sci Technol Inf. 2015;34(2):109-114+136 (in Chinese).

Yang H, Zhang WZ. Leading effect of the seventh member high-quality source rock of Yanchang Formation in Ordos basin during the enrichment of low-penetrating oil-gas accumulation: geology and geochemistry. Geochimica. 2005;34(2):147-54 (in Chinese).

Yang $\mathrm{H}$, Zhang $\mathrm{W}, \mathrm{Wu} \mathrm{K}$, et al. Uranium enrichment in lacustrine oil source rocks of the Chang 7 member of the Yanchang Formation, Ordos basin. China J Asian Earth Sci. 2010;39(4):285-93. https ://doi.org/10.1016/j.jseaes.2010.03.013.

Zhang WZ, Yang H, Peng PA, et al. The influence of late Triassic volcanism on the development of Chang 7 high grade hydrocarbon source rock in Ordos basin. Geochimica. 2009;38(6):573-82. https ://doi.org/10.3321/j.issn:0379-1726.2009.06.007 (in Chinese).

Zhang WZ, Yang H, Xie LQ, et al. Discovery of micro and nanofossils in high grade hydrocarbon source rocks of the Triassic Yanchang Formation Chang 7 member in Ordos basin and its scientific significance. Acta Palaeontol Sin. 2011;50(1):109-17 (in Chinese).

Zhang WZ, Yang H, Yang YH, et al. Petrology and element geochemistry and development environment of Yanchang Formation Chang 7 high quality source rock in Ordos basin. Geochmica. 2008;37(1):59-64. https://doi.org/10.19700/j.03791726.2008.01.008 (in Chinese).

Zhang Y, Zheng S, Gao B, et al. Distribution characteristic and enrichment factors of organic matter in upper Permian Dalong Formation of Shangsi section, Guangyuan. Sichuan Basin Earth Sci. 2017a;42(6):1008-25. https://doi.org/10.3799/dqkx.2017.534 (in Chinese).

Zhang WZ, Yang W, Xie LQ. Controls on organic matter accumulation in the Triassic Chang 7 lacustrine shale of the Ordos basin, central China. Int J Coal Geol. 2017b;183:38-51. https://doi. org/10.1016/j.coal.2017.09.015. 